\title{
CORRESPONDENCE
}

\section{Laser war games}

SIR - Zoological and anthropological evidence suggests that old conflict systems never die - they are ritualized. Antagonistic relationships are maintained in principle, but rendered progressively less dangerous as destructive behaviour gives way to display.

If increasing proportions of United States and Soviet military budgets are to be devoted to "laser weapons" (Nature 15 January, pages 109-111), this trend should be welcomed as a real sign of international relaxation. Strikingly coloured laser beams of spectacular power can be directed harmlessly into space at regular intervals, with none of the unfortunate ambiguity of intention and inelegance of effect which attend the launching of nuclear missiles. In due course, as Capitalist and Communist take their honoured places in history with Royalist and Roundhead, the "Firing of the Lasers" will no doubt become a public spectacle in the same class as the "Changing of the Guard"'

\section{Newtown, Australia}

\section{Exhibition policy}

SIR - The debate launched by Dr Halstead on the present orientation of the Natural History Museum at South Kensington, having centred on philosophical issues, leaves aside what I consider the main point. That is that because space has been made for new exhibits, the quality of which I will not discuss, many of the established collections are no longer on display. This was a shock to me when I revisited this institution last autumn for the first time in many years. As a kid in the "fifties my parents took me to London every year and the Natural History Museum was my favourite place to visit. Those visits were certainly important in shaping my vocation for systematic biology. I especially enjoyed those Victorian cabinets full of shells and insects that present managers have eliminated. I believe that for a child it is more exciting to open drawers full of bugs than to push buttons to see clades lighting up. I believe a natural history museum should be a display of as representative as possible a sample of the taxonomic diversity of the living world. Didactic exhibits on the causes of this diversity (evolution) or the techniques used by systematicians should complement the collections and if there is no space available for them, such exhibits could just as well go into the Science Museum.

There is certainly less work involved in preparing displays of stuffed or pickled animals than flashy exhibits on modern biology and maybe the increase (Parkinsonian?) in staff specialized in exhibit preparation, as testified by position openings advertised in Nature, is more relevant to the disappearance of collections from the public galleries of the British Museum than are ideologies impregnating the staff.

Department of Botany, V. Demolinin

University of Liège, Belgium

Corrigendum: In the letter "Energetic consensus" from F.H. Malpress, page 335 in Nature of 22 January, the units in the third equation should be kcal mol-1, and not kcal.
SIR - How charming that theological and political issues have come back into zoology'. Halstead ${ }^{2}$ says he is not worried if Marxism creeps into the Natural History Museum, though he does object to "unsubstantiated assertion" while at the same time he objects to different views presented by various sections of the museum - does this not show a due eclecticism on the museum's part?

Halstead's latest contribution ${ }^{2}$ is a direct criticism of the museum's Public Services Department. May I mention my own experience with this department, and its head, Dr Roger Miles? Having been asked some time ago to advise on an exhibition concerned with human perception, I later wrote a fairly detailed criticism of the results, in an editorial of the journal Perception ${ }^{3}$. The response was not the usual rebuttal, but quite the reverse Dr Miles immediately wrote inviting me to suggest plans for a complete redesign of this exhibition, and to attend the planning meetings and essentially to write the commentaries. This we have done. Whatever the result when it appears, this is evidence that the museum takes criticism seriously and acts with unusual generosity in seeking the help and advice of people outside its staff. Having also just given the museum's Christmas lectures, and so interacted again with the Public Services Department, I must say that in my opinion they have wholly commendable enthusiasm, and scholarship, as well as willingness to accept and act on well meant criticism.

Possibly scientists and writers who have not had experience designing exhibitions do not realize the difficulties. In a book, one can give graded qualifications, and cite rival views; and books are written for particular readerships whose background knowledge and interests may be assumed. But large public exhibitions must cater for children and expert authorities. They should be authoritative and balanced according to present knowledge, while also stimulating naive questions and deep questions for future research. To achieve this with an absolute minimum of text is possible only within limits, which we would all surely like to extend. The Natural History Museum should not merely be preserved as a museum of itself.

\section{Department of Anatomy,}

The Medical School, Bristol, UK

1. Halstead, L. B. Nature 288, 208 (1980)

2. Halstead, L. B. Nature 289, 106-107 (1981)

3. Gregory, R. L. Perception 7, 1 (1978)

\section{SIR - May I, as a voluntary worker in the} Education Department of the Natural History Museum, add a word to the current discussion in your pages.

I understand as little of cladistics as some of your correspondents seem to, but I wish to put in an ardent plea against the steady destruction of the museum by the Public Services Department. The present policy of tearing up by the roots so many of the excellent, clear, logical and didactically ideal displays and replacing them with gimmicky exhibitions that certainly amuse, but do not instruct, is painful to observe. All is now flashing lights, obscure working-models (all too frequently out of order from over-use by the under-tens), complicated texts that appear on screens only to disappear when you take your finger off the button before having read or digested them and strange puzzles that nobody has yet understood. These new, trendy, expensive displays, in which, as D. T. Donovan so rightly points out (Nature 1/8 January, p.105), original specimens hardly figure or are replaced by colour-photographs or plastic models, reach their tasteless peak in the disco/fun-fair atmosphere of the Human Biology Hall and provide mainly pseudoinformation from which little is learnt and even less retained.

I must except from this criticism the excellent new ecology exhibit. It is a pity that it has been relegated to a long narrow hall and disposed in zig-zag fashion so that visitors are constantly colliding as they slalom their way from side to side, missing many of the showcases in the process.

The loss of the remarkable comparative anatomy section as a teaching-aid on adaptation is a tragedy . . . or is its disappearance really a confirmation of more sinister motives?

As for the scattering of the dinosaurs, a logical teaching tour has become a magica! mystery tour, with specimens appearing and vanishing from week to week. Poor Tyrannosaurus rex remains in splendid isolation in the old hall; if you can find him. Our splendid Diplodocus is completely dwarfed by the enormous proportions of the great central hall, yet he cannot even stretch out his tail as in the old gallery, and his head, inserted with difficulty under the bridge, all but protrudes out of the front entrance, where it can only be studied by obstructing and annoying the incoming visitors. This break-up of the fossil collections, for which the right wing of the museum was specifically designed, is a major disaster and if they really mean to dismantle the fossil mammal gallery, I for one will give up and go, much as I love the work. (Name and address withheld -ED. Nature)

\section{Soviet rumbles}

SIR - Ms Vera Rich has given an inaccurate account of the status of plate tectonics in the Soviet Union (see Nature 14 August 1980 , p.652). Professor V. V. Beloussov (who is a Corresponding Member of the Academy, not a full Academician, and my close personal friend) has no control over what his fellow members of the Academy write or state about plate tectonics. Academician Peyve, also a close personal friend and director of the Institute of Geology of the Academy of Sciences, has published pro-plate tectonics articles with more than 30 of his colleagues since 1966. There are no restrictions whatsoever within the Academy against publishing papers on plate tectonics, and more than 3,000 proplate tectonics articles a year are published in the Soviet Union by members, not only of the Academy of Sciences and its branches, but also of regional institutes and academies.

I am an American citizen, not a Soviet citizen, and am fairly well known for my views against plate tectonics. However, I wish to see the scientists of the Soviet Union given their due. Some of the finest pro-plate tectonics literature in the world is being published in the Soviet Union.

Tulsa, Oklahoma
A. A. MEYERHOFF 